\title{
AL-QUR'AN DAN SASTRA: ANTARA ETIKA, ESTETIKA, DAN PROFETIKA
}

\section{Al-Qur'an and Literature: Between Ethics, Aesthetics, and Prophetic}

\author{
القرآن والأدب: بين الأخلاق والجماليات والمهنية
}

\author{
Abd. Aziz \\ Institut PTIQ Jakarta, Indonesia \\ abdaziz@ptiq.ac.id
}

\begin{abstract}
Abstrak
Tulisan ini bertujuan untuk mengupas tentang makan-makna ayat dalam Al-Qur'an yang sesungguhnya merupakan sebuah pesan, membawa ingatan kepada realita, yaitu bahwa kendati terintegrasi ke dalam sistem linguistik bahasa Arab, teks Al-Qur'an mempunyai ciri khas tersendiri. Al-Qur'an, sebuah teks unik, memanfaatkan 'sandi linguistik' tertentu yang ramai dan dinamis guna mentransfer 'risalah' khasnya itu. Kekhasan itu yang kemudian mendapatkan rekognisi dari kalangan orang Arab, bahkan justru membuat kekaguman pihakpihak yang menyerang risalah tersebut. Berawal dari berbagai kekhasan yang dimiliki AlQur'an, dan apalagi muncul tantangan dari Al-Qur'an itu sendiri kepada orang Arab untuk mereplikasi, menduplikasi, dan membuat sesuatu yang baru atas sejumlah teks yang semisal Al-Qur'an, misalnya surat-surat pendeknya, melahirkan gagasan 'ketidakberbandingan (ijaz)' Al-Qur'an yang absolut. Sebuah kajian atas pemecahan kompleksitas sosial yang dapat menciptakan harmoni di tengah variabilitas masyarakat.
\end{abstract}

Kata Kunci: Sastra, Harmoni, Al-Qur'an

\begin{abstract}
This paper aims to explore the meaning of a verse in the Al-Qur'an which is actually a message, bringing memories to reality, namely that although it is integrated into the Arabic linguistic system, the text of the Al-Qur'an has its own characteristics. The Qur'an, a unique text, makes use of a certain lively and dynamic 'linguistic code' to transfer its distinctive 'treatise'. This peculiarity was later recognized by the Arabs, and even made the people who attacked the treatise admire. Starting from the various uniqueness possessed by the Al-Qur'an, and moreover, there arose a challenge from the Qur'an itself to the Arabs to replicate, duplicate, and create something new on a number of texts such as the Qur'an, for example the letter-a letter in short, gave birth to the idea of the absolute 'incommensurability (i'jaz)' of the Qur'an. A study of solving social complexity that can create harmony amidst the variability of society.
\end{abstract}

Keywords: Literature, Harmony, Al-Qur'an

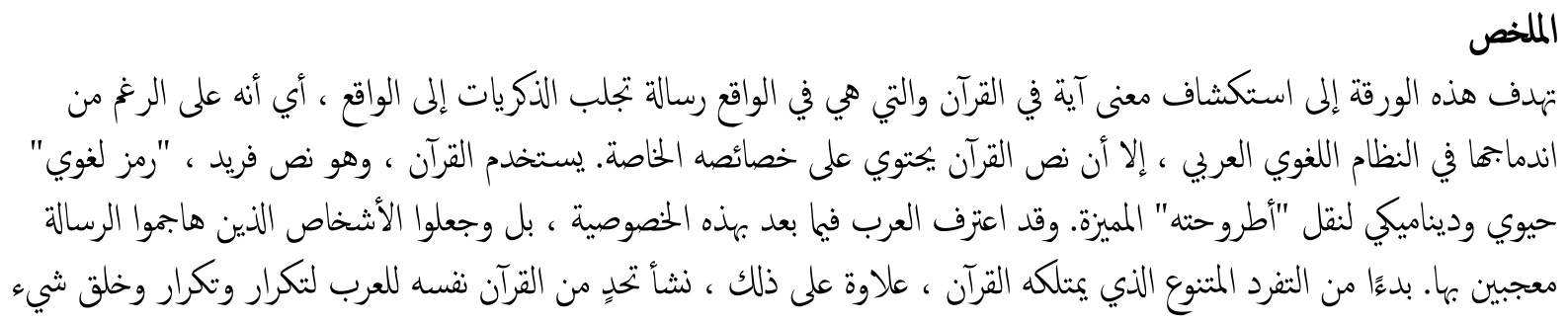




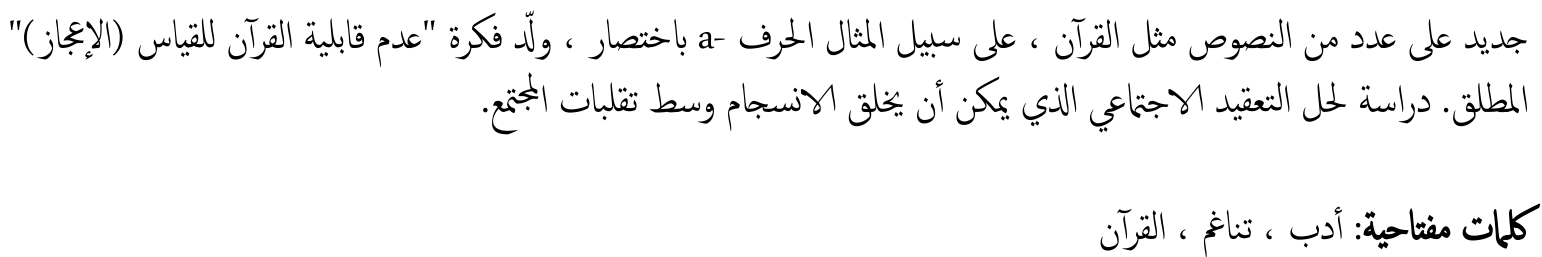

\section{Pendahuluan}

Mulai dari pewahyuan, Al-Qur'an sudah 'lihai' menangkap imajinasi masyarakat Arab melalui kekhasan dan keunikan linguistiknya. Padahal, orang Arab berupaya semaksimal mungkin untuk memahami daya kedigdayaan (i'jaz) pengaruh Al-Qur'an melalui identifikasi tipe-tipe teks tertentu yang sudah mereka ketahui, untuk kemudian mereka lempar ke publik untuk dinilai secara kultur kecerdasan seni merangkai kata menjadi estetika kebahasaan. Faktanya, semua data dan kemampuan yang diajukan terbantahkan dan tertolak oleh Al-Qur'an sendiri. Fakta ini diindikatori oleh tindakan mereka yang menjelaskan bahwa Al-Qur'an itu adalah 'syair' dan bahkan menuduh penyusunnya adalah nabi Muhammad Saw. Kemudian tuduhan semacam itu dibantah dalam Q.S. Yasin/36: 69. Tidak berhenti di situ, ada saja tindakan mereka, yaitu ketika masyarakat Arab saat itu mendakwakan nabi Muhammad Saw sebagai penenung. Namun, cukup melegakan jawaban Al-Qur'an dalam QS. al-Tur/52: 29.

Kaum kafir ketika itu merencanakan upaya bagaimana Al-Qur'an itu hanyalah runtutan cerita yang dibuat-buat nabi Muhammad Saw, sehingga menimbulkan ketidakpercayaan di khalayak publik bahwa itu adalah wahyu dari Tuhannya, bahkan teks Al-Qur'an yang disampaikan melalui lisannya benar-benar 'berita hoax.' Kalau hanya sekadar seperti itu, mereka menganggapnya juga bisa melakukan seperti Muhammad.

Lagi-lagi, Al-Qur'an tidak diam begitu saja dalam menghadapi informasiinformasi yang didesas-desuskan mereka, dengan cara mempublikasikan sebuah 'counter balik' kepada mereka atau dengan pernyataan yang lebih tegas, menantang sekaligus menentang mereka melalui upaya mereka untuk membuat 'sepuluh surat persis dengan Al-Qur'an' (Q.S. Hud/11: 13). Faktanya, kemauan mereka tidak sejurus dengan kemampuan mereka. Al-Qur'an menantangnya dengan cara yang lebih 'soft' atau lebih menurunkan level tantangannya, yang tujuannya adalah memudahkan mereka, dengan meminta lebih spesifik atau lebih sedikit saja membuat yang mulanya sepuluh menjadi satu surat (Q.S. Yunus/10: 38). Dengan pola sistematis lantaran menyesuaikan kemampuan mereka, akhirnya step paling belakang adalah Allah Swt tunjukkan kekalahan mereka melalui kesalahan absolut atas tindakan yang menantang dan menentang keotentikan Al-Qur'an. ${ }^{1}$

Eksistensi Al-Qur'an dan bahasanya masih terawat hingga kini. Bahasa Arab yang menjadi bahasa Arab juga terangkat keberadaannya karena digunakan Al-Qur'an sebagai bahasa firman. Faktor ini yang menyebabkan Al-Qur'an senantiasa diamati, dipelajari, dipahami, diperlakukan sebagai objek dan subjek studi, dan ditafsirkan.

Sebelum diturunkan Al-Qur'an diturunkan, bahasa dan sastra Arab memang sangat familiar dan melekat erat ke dalam 'sukma' kepribadian orang Arab. Bahasa

${ }^{1}$ Marzuki Wahid, Studi Al-Quran Kontemporer Perspektif Islam Dan Barat (Bandung: CV. Pustaka Setia, 2005).

148 | al- Burhan. Kajian Ilmu dan Pengembangan Budaya Al-Qur'an, Vol. 20, No. 1, Juni 2020: 129-163. 


\section{Abd. Aziz}

yang digunakan dan karya sastra yang diciptakan mereka adalah suatu hal yang menjadi bukti. Simbol keagungan mereka anggap - tidak ada yang menandinginya terletak di dalam keindahan dan bahasa yang mereka gunakan. Itu sebabnya muncul pengakuan di tengah mereka, bahwa jika mereka mampu memproduksi puisi dan karya sastra termasuk pribadi yang jenius. Manakala Al-Qur'an hadir, kemampuan bahasa dan sastra mereka seolah 'terlucuti' oleh keindahan bahasa Al-Qur'an yang tidak pernah ada sebelumnya. Ini yang kemudian mereka merefer Al-Qur'an sebagai sumber inspirasi ke dalam menjadi gaya bahasa dan sastra Arab mereka.

Atas dasar itu semua, kemudian menjadi penting bagi seseorang yang berkedudukan sebagai sastrawan. Maksudnya, nilai kesusasteraan Al-Qur'an yang berbasis Al-Qur'an itu sendiri, tidak sekadar sebagai media merekonstruksi kenyataan empiris, namun lebih dari itu semua, yakni tuntutan untuk mengoptimalkan implementasi kesadaran teologis transendental-spiritual ${ }^{2} 3$, yang kemudian menjadi norma etik sastrawan dalam melakukan studinya terhadap teks Al-Qur'an, sehingga manakala muncul pengabaian atas syarat etik tersebut, dianggap sebagai bentuk penyimpangan, baik pada aspek tindakan amoralisasi estetik maupun pada aspek aksional pencemaran agama dan budaya, yang pada gilirannya ia terkena 'singgungan berat' dalam QS. al-Shu'ara/26: 224-227.

Tidak saja dari kalangan sastrawan, nyatanya tidak sedikit muslim yang menekuni Al-Qur'an sebagai karya sastra, dan mengekspose rahasia keindahan dan kedidigdayaan estetika bahasanya atau yang sering kita sebut dengan kemukjizatannya. Khususnya pada jenang perguruan tinggi berbasis ilmu Al-Qur'an, sastra, dan studi Islam lainnya. Kemukjizatan estetis Al-Qur'an ini yang disebut Wildana and Laily Fitriani, sebagai bukti keilahian-Nya.

Kondisi kini tentu tidak sama dengan miliu saat Al-Qur'an diturunkan pada waktu itu, yaitu tantangan Al-Qur'an ditujukan kepada siapa pun yang hendak menyainginya atau pun para ahli di bidangnya, diharuskan menyertakan potensi dirinya dengan kemampuan memahami secara lengkap tentang keunggulan sastra dari Al-Qur'an ${ }^{4}$. Bisa jadi, ketiadaan fakta historis tersebut, Al-Qur'an tidak dapat 'unjuk diri' akan kedigdayaan estetika bahasanya yang membuat siapa saja terpesona. Tanpa fakta itu pula, bangsa Arab tidak barangkali tidak menganggapnya sebagai firman Allah yang sangat indah. Karena itu, yang menjadikan Al-Qur'an diterima sebagai wahyu-Nya adalah Al-Qur'an mampu melampaui level kecerdasan bangsa Arab yang memang ketika itu perkembangan sastra sangat luar biasa masif, dan ini juga yang membuatnya bukan karya manusia mana pun. ${ }^{5}$

Relevansi ketidakberbandingan (i'jaz)’ Al-Qur'an di tengah komunitas kesastraan dunia, membutuhkan suatu interpretasi cerdas yang bermuatan sastrawi. Terlebih, proses interpretasi terhadap muatan substansial Al-Qur'an tidak pernah berakhir dan kerap menghadirkan sesuatu yang beragam seiring masa ini berjalan. Interpretasi yang memiliki relevansi dengan dunia sosial di luar Al-Qur'an, mau tidak mau harus selalu

${ }^{2}$ Hamdy Salad, Agama Seni: Refleksi Teologis Dalam Ruang Estetik (Yogyakarta: Yayasan Semesta, 2000).

${ }^{3}$ Hamdy Salad, Refleksi Teologis Dalam Ruang Estetik (Yogyakarta: Yayasan Semesta, 200o).

${ }^{4}$ Abd Aziz and Saihu Saihu, "Interpretasi Humanistik Kebahasaan: Upaya Kontekstualisasi Kaidah Bahasa Arab," Arabiyatuna: Jurnal Bahasa Arab 3, no. 2 (2019): 299, https://doi.org/10.29240/jba.v3i2.10oo.

${ }^{5}$ W Wildana and Laily Fitriani, Sastra Arab Dan Lintas Budaya (Malang: UIN-Malang Press, 2008). 
dikembangkan, agar pesannya tidak menjadi subjek manipulasi pragmatis atas berbagai kepentingan politis.

Islam sebagai suatu keyakinan universal bagi pemeluknya, tentu tidak terpisahkan dengan proses interpretasi di dalamnya. Kendati begitu, harus diakui bahwa adanya perbedaan antara makna dan konteks yang membuat signifikansi maknanya menjadi lebih kontekstual, dipastikan selalu mengalami dinamika perubahan yang mungkin saja disebabkan oleh faktor historisitas dan signifikansinya. ${ }^{6}$ Signifikansi ini yang seharusnya menjadi kesadaran diri pembaca Al-Qur'an untuk mengaitkan secara rasional dengan makna yang hendak diperolehnya, sehingga dapat menelurkan interpretasi yang 'cukup valid,' selama tidak melepaskan prinsip-prinsip metodologis untuk membuat loncatan logika ideologi yang diinginkan. Atau dalam pernyataan Marzuki Wahid, jika teks itu adalah sejarah, kendati bersumber dari Tuhan secara orisinalitas, maka interpretasinya adalah mutlak manusiawi. ${ }^{7}$ Oleh karena itu, urgen jika ingin menyebut demikian, harus ada harmonisasi realitas objektif (dunia fakta) dan realitas imajinatif (dunia maya) untuk menyempurnakan atau sekurangnya melengkapi properti estetika Al-Qur'an. Dengan demikian, ini akan mengarah kepada tujuan utama sastra dalam perspektif Al-Qur'an, yaitu membangun kesadaran dimensi spiritual yang mewujud dalam rasa rindu Tuhan dan mengonstruk rasa kesadaran diri manusia atas dirinya sendiri dan lingkungan sosialnya. ${ }^{8}$

Realitas yang dibangun berasal dari norma, peristiwa, dan pandangan hidup lainnya, dalam proses kreatif seorang sastrawan ketika menghadapi fakta-fakta yang ditemuinya di lingkungan sosial. Dalam kaitan proses kreatif itulah, ia dituntut memiliki kapabilitas mengintegrasikan realitas subjektif (nalar teologis) dan realitas objektif (nalar kultural), sebagai basis fundamental atas realita imajinatif (kesadaran ekspresionistik). Dari situlah muncul sastrawan dengan kepribadian yang ketika menghadapi fakta realnya, ia akan memiliki jiwa protes karena berdasarkan ketidakpuasannya terhadap realita yang ada. Ia berupaya memiliki sikap untuk mengimajinasikan realitas yang berbeda dengan sebelumnya alias baru, sebelum jiwa protes itu ia ekspresikan. Ekspresi itu selanjutnya menjadi produk sastranya ${ }^{9}$. Sebab itu, proses kreativitas yang merambah kepada sikapnya tersebut merupakan format kedalaman kredo sekaligus daya penghayatan dirinya sebagai seorang sastrawan terhadap agama yang diyakininya. Akhirnya, nilai-nilai dari Al-Qur'an merasuk ke dalam jiwa, dan termasuk ke dalam produk sastrawinya. Selain itu, di tengah proses kreativitas sastranya, ia mengemban amanat Q.S. al-An‘am: 164; Q.S. al-Isra/17: 15.

Penjelasan ini mengarah kepada pernyataan bahwa sastra di tengah-tengah AlQur'an mempunyai relasi subordinatif atas agama. Utamanya pula, karakteristik sastra sebagai wujud ekspresi estetik memosisikan substansinya untuk menyingkronisasikan antara misi transendental yang lebih menjurus ke arah keinginan ilahi dan misi kultural yang lebih ke arah keinginan manusiawi.

${ }^{6}$ Abd Aziz, Athoillah Islamy, and Saihu, "Existence of Naht Method in the Development of Contemporary Arabic Language," Taqdir: Jurnal Pendidikan Bahasa Arab Dan Kebahasaaraban 5, no. 2 (2019): 19-28, https://doi.org/https://doi.org/https://doi.org/10.19109/taqdir.v5i2.4926.

${ }^{7}$ Wahid, Studi Al-Quran Kontemporer Perspektif Islam Dan Barat.

${ }^{8}$ David James, Islamic Art: An Introduction (London-New York: Hamlyn, 1974).

9 Jiwa Atmaja, Notasi Tentang Novel Dan Semiotika Sastra (Ende: Nusa Indah, 1986). 


\section{Al-Qur'an Sastra Ideal yang Menginspirasi}

Studi sastra melalui teori sastra interdisciplinary memiliki ragam kelebihan secara fungsional. Antara lain yaitu studi sastra tidak lagi mengalienasikan dirinya dari kajian-kajian kemanusiaan pragmatis. Sebab itu, peneliti sastra harus membekali nalarnya dengan keilmuan di luar sastra. Dengan ungkapan lain, jika mengadopsi istilah Sukron Kamil, kajian sastra menyesuaikan 'pakaian kecenderungannya' kepada sistem pendidikan tinggi kontemporer di Barat, yang menyingkirkan pendidikan monodisipliner. ${ }^{10}$

Hal di atas, tentu saja mengabaikan minta studi sastra di Indonesia yang ketika kajiannya merelasikan sastra dan Islam, membuatnya berkutat kepada paradigma berpikir tentang 'tidak mesranya' antara sastra dan Islam itu sendiri. Atau memilih pernyataan lain, yaitu kerap ada pihak yang tidak percaya dan meragukan keterkaitan antara keduanya tersebut.

Ada juga selain faktor tersebut yang turut memengaruhi ketiadaan relasi keduanya, yaitu sedikit atensi dari pemimpin, ulama, intelektual, cendekiawan atas sastra. Bahkan, masih ada yang menganggapnya produk sastra sebagai produk imajinatif yang 'recehan.' Bila mau ditelusuri, faktor di atas merujuk, pertama, suatu gagasan salah seorang ahli fikih India yang dinobatkan menjadi mufti istana Kerajaan Aceh Darussalam pada pemerintahan Sultan Iskandar II (1636-1641 M), Syaykh Nur alDin al-Raniri (w. 1069 H/1658 M). Misalnya, Sri Rama dan Hikayat Indra Putra sebagai karya sastra, dianggapnya sebagai hasil karya sastra yang hanya penuh dengan mitos, khayalan, dan dongeng. Bahkan, ia menyatakan dalam Sirat\} al-Mustaqim (Jalan Lurus [1643]), karya sastra harus dibersihkan dengan cara istinja' dari muslim. Untuk itu, anak-anak tidak menikmati bacaan sastra, dan ini disarankannya dalam Bustan alSalatin (Taman Raja-raja [1637]). ${ }^{11}$ Kedua, kebebasan berkreasi atau licentia poetika yang merupakan keniscayaan dalam sastra, menyebabkan diragukannya pengakuan Islam terhadap sastra itu sendiri. Ini dimaklumi oleh sebab kerap muncul respons umat Islam atas suatu karya sastra profan yang berseberangan dengan prinsip-prinsip moral Islam, terutama karya sastra yang menistakan agama. Sebenarnya, reaksi ini tidak hanya muslim yang ada dalam Islam, tetapi juga ada pada pemeluk Kristen. ${ }^{12}$

Atas dasar itu, watak prohibisionis dilekatkan kepada Islam yang pada gilirannya menyebabkan kemunculan aksi pengawasan terhadap segala bentuk kreativitas sastra. ${ }^{13}$ Yang menjadi problematik sehingga menjadi kendala tersendiri, yaitu terkait sikap memandang produk sastra sebagai karya imajinatif dengan menyetarakan dengan sikap menilai karya non-sastra. Sebagai penegasan atas problematika ini, yaitu pemahaman tentang kebebasan berekspresi yang terjadi di kultur Timur dan kultur Barat. Hal ini tampak dalam hal minimnya kepekaan pihak-pihak sekuler terhadap sesuatu yang berbau sakralitas, dan ini diafirmasi pengakuannya oleh kaum beragama dengan mengatasnamakan liberalitas puritan, misalnya yang terjadi dalam kasus Salman Rushdie. Pemahaman yang seperti ini dapat diakui bahwa kalangan sastrawan

${ }^{10}$ Sukron Kamil, Naji>b Mahfu>z, Sastra Islam Dan Politik, Studi Semiotik Terhadap Novel Aula $>$ d Ha>ratina, 1 (Jakarta: Dian Rakyat, 2013).

${ }^{11}$ Liaw Yock Fang, Sejarah Kesusastraan Melayu Klasik Jilid I (Jakarta: Erlangga, 1991).

${ }^{12}$ Dan Brown, The Davinci Code, trans. Isma B. Koesalamwardi, vol. XXIII (Jakarta: Serambi, 2006).

${ }^{13}$ Marwan Saridjo, Sastra Dan Agama, Tinjauan Kesusastraan Indonesia Modern Bercorak Islam (Jakarta: Permadani, 2006). 
beraliran romantis dan selainnya, terwujud anggapan bahwa hak mereka adalah memiliki kebebasan berekspresi seluas-luasnya, bahkan anggapan yang lebih tajam lagi, sikap kebebasan berekspresi itu seolah menyamakan atau memperlakukan diri seperti 'Tuhan.' Kredo yang dibangun mereka adalah 'Aku bak Tuhan yang berkuasa dalam pikiran dan jiwaku terdalam.' Kebebasan tersebut membuatnya sebebas Tuhan yang menciptakan dunia dan segala apa saja di dalamnya. ${ }^{14}$ Demikian bangunan analogi mereka terhadap eksistensi dan produk sastra mereka. Oleh sebab itu, lebih jauh, Sukron Kamil, menegaskan, Islam tidak saja menerima entitas sastra - kendati perlu ada penegasan, harus sesuai dengan moralitas dan spiritualitas - tetapi basis fundamental ajarannya sendiri, Al-Qur'an, merupakan kitab suci yang mempunyai sisi dan ornamen sastra yang luar biasa. Bahkan, menurutnya, Al-Qur'an merupakan karya sastra ideal.

Menarik untuk dikorelasikan, bahwa sastra Islam tidak hanya sastra Arab saja. Pasalnya, Islam itu sendiri melampaui limit-limit kebahasaan. Ini menjadi benderang, ketika menyatakan bahwa sastra Islam bukan 'musuh' sastra Barat. Sebab, Goethe (yang lahir tahun 1749), melalui sejumlah karyanya, meyakini keagungan Al-Qur'an, keesaan Tuhan, dan kenabian nabi Muhammad Saw. Ini menunjukkan bahwa dalam sastra Barat terdapat sastra Islam. Apalagi, Barat juga menolak aspek-aspek ateisme dan materialisme sebagai format paganisme baru yang berlawanan dengan prinsipprinsip Islam. Umpamanya lagi, dalam konteks realisme Barat, yang ditolak pengusung sastra Islam antara lain adalah berhenti pada realitas yang disampaikan apa adanya dengan tidak melakukan pemihakan. Sejumlah karya sastra Islam, ada kecenderungan menjauhkan pengaruh buruk kepada pembaca sastra, sehingga tren tersebut membuat karya sastra lebih mengutamakan realita yang baik dan lurus-lurus saja. Misalnya, realita pelacuran yang dipublikasikan oleh suatu karya sastra. ${ }^{15}$

Penjelasan di atas, berbanding berbeda dengan eksplanasi Abdul Hadi W.M, bahwa penyebutan sastra Islam berbeda dengan penyebutan sastra Barat, sastra Timur, sastra Arab, sastra Amerika, atau sastra Indonesia. Penyebutan tersebut menunjukkan kejelasan definisi, bahasa, trend etnologi, terutama batasan geografis. Abdul Hadi W.M berpandangan bahwa eksistensi karya sastra Islam di Indonesia sudah sejak abad ke-14, bersamaan dengan pengaruh Islam yang meluas ke seluruh wilayah Nusantara. Sebelumnya, hal ini disebabkan faktor Indonesia yang pada saat itu baru ada Melayu, sehingga yang dikenal adalah kesusastraan Melayu Islam. Sedangkan para tokohnya di bidang sastra Islam, antara lain adalah Hamzah Fansuri, Bukhari al-Jauhari, Syamsudin Sumatrani, Nuruddin al-Raniri ${ }^{16}$.

Sebagaimana penjelasan di atas, terwujud semacam relasi antara produk sastra dan kehidupan di luar dirinya, dan ini dapat diperlihatkan melalui penelusuran tentang gagasan dalam puisi, novel, drama, sebagai suatu karya sastra. Yang ingin ditunjukkan dalam penjelasan ini adalah bahwa karya sastra itu tidak otonom. Untuk itu, muatan atas gagasan suatu karya sastra kerapkali dikemas dalam suatu seni sastra dan terbungkus secara implisit. Ini berarti studi terhadapnya dilakukan dengan menerapkan hubungan ganda, yaitu gagasan dalam suatu karya sastra dan keindahan

\footnotetext{
${ }^{14}$ Abdul Hadi W.M., Islam, Cakrawala Estetik Dan Budaya (Jakarta: Pustaka Firdaus, 200o).

${ }^{15}$ Hilmi Muh\}ammad Al-Qa'ud, Al-Waqiizyah Al-Islamiyyah Fi Riwayat Najib Al-Kaylani, Dira>sah Naqdiyyah (Riyad: Maktabah al-'Abikan, n.d.).

${ }^{16}$ Ekarini Saraswati, "Pribadi Dalam Novel Ayat-Ayat Cinta Dan Laskar Pelangi: Telaah Psikoanalisis Sigmund Freud," Artikulasi 12, no. 2 (2011): 883.
}

152 | al-@urhan: Kajian Ilmu dan Pengembangan Budaya Al-Qur'an, Vol. 20, No. 1, Juni 2020: 129-163. 


\section{Abd. Aziz}

di dalamnya sebagai suatu seni sastra. Gagasan secara implisit yang terdapat di dalamnya, salah satunya adalah tasawuf. ${ }^{17}$

Sejalan dengan itu istilah tersebut, tasawuf dapat diartikan sebagai a member of a Muslim group who try to become united with God through prayer and meditation and by living a very simple, strict life (anggota komunitas Muslim yang berusaha bersatu dengan Tuhan melalui doa dan meditasi serta menjalani kehidupan yang sangat sederhana dan tegas). Dalam Kamus Besar Bahasa Indonesia (KBBI), lema tasawuf dijelaskan sebagai ajaran mengenal dan mendekatkan diri kepada Allah, sehingga memperoleh hubungan langsung dengan-Nya. ${ }^{18}$ Lema tasawuf juga memiliki kedekatan makna (sinonim) dengan istilah mistik, kebatinan, suluk, tarekat; ilmu sufi. Dengan demikian, gagasan tasawuf yang tercakup dalam karya sastra harus dimaknai sebagai gagasan pemikiran yang harus didalami melalui pranata khusus yang bertalian dengan 'sistem karya sastra' yang patuh kepada konvensi-konvensi dalam karya itu sendiri. Misalnya, dalam novel, gagasan tasawuf bisa jadi tampak pada tataran penokohan, alur, tema, dan latar. Tentu berbeda jika objeknya adalah puisi. ${ }^{19}$

Sastra Islam hingga kini, merupakan suatu konsep yang seringkali mendapatkan tanggapan dan atensi dari berbagai kalangan penyair dan seniman. Misalnya tanggapan yang datang dari Muktamar Islam ketika mengategorikan suatu sastra Islam. ${ }^{20}$ Karena itu, seringkali sastra Islam dihubungkan dengan sebutan 'sastra yang berbasis agama.' Ketika suatu karya sastra memuat budaya dan nilai ajaran agama, itu berarti kandungannya adalah nilai-nilai ajaran agama, moralitas, dan unsur-unsur estetika sastra. ${ }^{21}$ Ukuran pengategorian suatu karya sastra masuk ke dalam wilayah sastra Islam adalah salah satunya melalui terminologi-terminologi keagamaan yang dimuat di dalamnya. Inilah pengertian tentang nilai-nilai keagamaan dalam suatu karya sastra Islam yang tertanam di dalam benak sejumlah pihak.

Sekurangnya, sastra Islam, dalam keterangan Sukron Kamil, adalah sastra yang mempublikasikan sistem keyakinan dan ajaran Islam. Misalnya, yang bertalian dengan isu-isu kemanusiaan, mengangkat dan mempromosikan tokoh-tokoh Islam, mengkritik fakta-fakta sosial yang tidak sealur dengan nilai-nilai Islam. Dengan kata lain, sastra Islam adalah sastra yang memiliki komitmen atau yang tidak berlawanan dengan prinsip-prinsip Islam. ${ }^{22}$

Sastra berkarakter seperti itu di Indonesia, dikenal dengan ragam istilah, antaranya: 1) Sastra sufistik, karya sastra yang lebih mengutamakan pembersihan hati n.d.

${ }^{17}$ Heri Isnaini, “Gagasan Tasawuf Pada Kumpulan Puisi Isyarat Karya Kuntowijoyo," Semantik,

${ }^{18}$ Departemen Pendidikan Nasional, Kamus Tesaurus Bahasa Indonesia (Jakarta: Pusat Bahasa, 2008).

${ }^{19}$ Isnaini. H, “Gagasan Tasawuf Pada Kumpulan Puisi Isyarat Karya Kuntowijoyo," Tesis, 2012, 8799.

${ }^{20}$ Muktamar Islam ini untuk al-Adab al-Islami, yang dilaksanakan dalam tiga kali muktamar. Pertama dilaksanakan di India, kedua di Universitas Madinah Saudi Arabia dan ketiga di Universitas Imam Muhammad Ibnu Sa'ud Riyad. Muktamar-muktamar ini melahirkan badan Sastra Islam tingkat Internasional yang diberi nama Rabit\}ah al-Adab al-Islami al-'Alami yang diketuai oleh Ulama Besar India Syaikh Abu al-Hasan 'Ali al-Hasani al-Nadawi yang kemudian tahun 1994 diterbitkanlah Jurnal alAdab al-Islami.

${ }^{21}$ Santoso and Dan Dkk, Sastra Keagamaan Dalam Perkembangan Sastra Indonesia: Puisi 19461965 (Jakarta: Pusat Bahasa, Departemen Pendidikan Nasional, 2004).

${ }^{22}$ Kamil, Najib Mahfuz, Sastra Islam Dan Politik, Studi Semiotik Terhadap Novel Aulad Ha>ratina. 
(tazkiyah al-nafs) dengan menanamkan nilai-nilai akhlak luhur untuk lebih mendekatkan diri kepada Allah; 2) Sastra suluk, karya sastra yang melukiskan perjalanan spiritual seorang sufi yang memperoleh taraf di mana hubungan jiwanya telah dekat dengan Tuhan, yaitu mushahadah, penyaksian terhadap keesaan Allah; 3) Sastra transendental, karya sastra yang membahas Tuhan yang Transenden, dan sastra profetik, yaitu sastra yang dibentuk berdasarkan atau untuk tujuan menjelaskan tentang prinsip-prinsip kenabian (wahyu). ${ }^{23}$ Sebagaimana halnya, sastra sufistik, tepatnya dalam konteks ini, puisi sufistik, merupakan sastra Islam. Misalnya, menurut Yusuf Zaydan, puisi-puisi al-Jilani, merupakan puisi sufistik. ${ }^{24}$ atau bisa juga dikategorikan sebagai puisi agama. Pasalnya, berdasarkan penjelasan Hassan 'Abd alKarim, puisi agama dalam Islam adalah sumber pertama sastra sufistik, yang awal kemunculannya dalam Islam untuk mengembangkan dakwah Islam. ${ }^{25}$ Puisi kategori ini dimulai pada masa pemerintahan Bani Umayah, yang kelanjutannya tidak meneruskan gaya puisi Islam pada masa sebelumnya, sehingga munculnya puisi yang menurut terminologi Hassan 'Abd al-Karim, sebagai puisi religiositas (al-shi'r altadayyun). Puisi religiositas memiliki dua tujuan utama: Pertama, nasihat, peringatan tentang kehidupan dan gambaran akhirat. Kedua, kebijaksanaan keagamaan (alhjikmah al-diniyah) dan moralitas/etika (al-akhlaq). Puisi religiositas berkembang seiring dengan perkembangan kehidupan spiritual dalam masyarakat Islam. Tentu saja, tujuan-tujuan tersebut sejalan dengan nilai-nilai substansial Al-Qur'an.

Ketika suatu karya sastra Islam berbasis kepada Al-Qur'an, maka sekurangnya, relevansi ini memiliki benang merah dengan penjelasan Rosa, tentang tiga persyaratan umum, suatu karya sastra dikatakan sastra Islam, dalam hal ini, novel Islami, yaitu novel yang (a) penulisnya adalah seorang muslim yang sadar dan bertanggung jawab atas kesucian agama; (b) karya kreatif yang diproduksi sesuai dengan nilai-nilai ajaran Islam dan tidak bertentangan dengan syariat Islam; serta (c) karya yang memiliki daya tarik dan universal serta dapat bermanfaat bagi siapa saja, dan ini selaras dengan Islam sebagai agama fitrah. ${ }^{26}$ Sedangkan yang menjadi karakteristik konsep sastra Islam yang paling menonjol adalah seputar akhlak, moral, etika dan kemanusiaan. ${ }^{27}$

Saat ini, perkembangan terhadap apresiasi sastra Islam dapat dilihat dari beberapa trend yang ada, diantaranya;

a. Semakin beragamnya bentuk karya sastra Islam dalam bentuk cerpen, novel, drama maupun bentuk sastra yang lainnya. Keberagaman tema dan alur cerita yang diproduksi diikuti makin meningkat intelektual umat Islam Indonesia, berdampak pada semakin beragam latar belakang para pencipta sastra. Hal ini tentu memiliki pengaruh besar terhadap corak dan keanekaragaman karya-karya sastra Islam di Indonesia.

b. Pertumbuhan dan perkembangan sastra Islam di Indonesia mengalami perkembangan yang signifikan. Indikatornya tampak pada buku-buku Islam yang

${ }^{23}$ Moh. Syarifudin, "Sastra Qur'ani Dan Tantangan Sastra Islam Di Indonesia," vol. XII, n.d.

${ }^{24}$ Yu $>$ suf Zayda $>$ n, Di $>$ wa $>n$ 'Abd Al-Qa>dir Al-Ji>la>ni> (Beirut: Da>r al-Jil, n.d.).

${ }_{25} \mathrm{H}\{$ assa $>\mathrm{n}$ 'Abd Al-Kari>m, Al-Tas\}awwuf Fi> Al-Shi'r Al-'Arabi>, Nash'Atuhu Wa Tat\}awwuruhu H\}atta> A<khir Al-Qarn Al-Tha>lith Al-Hijri (Kairo: Maktabah al-Anjilu> al-Mis\}riyyah, 1954).

${ }^{26}$ Asep Supriadi, "Transformasi Nilai-Nilai Ajaran Islam Dalam Ayat-Ayat Cinta Karya Habiburrahman El-Shirazy: Kajian Interteks” (Tesis, 2006).

${ }^{27}$ M. Ahmad, Membumikan Islam Di Indonesia (Gorontalo: Panitia Seminar Nasional, 2003).

154 | al-@urhan: Kajian Ilmu dan Pengembangan Budaya Al-Qur'an, Vol. 20, No. 1, Juni 2020: 129-163. 


\section{Abd. Aziz}

laris terjual, baik fiksi maupun non-fiksi. Kondisi ini mengiringi semakin banyaknya industri sejumlah penerbit yang memproduksi buku-buku sastra.

c. Penerbitan buku-buku sastra, terutama novel dan cerpen, berdampak pada kemunculan komunitas para penulis dalam bidang sastra. ${ }^{28}$

Kehidupan sastra Islam di Indonesia dewasa ini mengalami perkembangan yang sangat pesat. Ini ditandai dengan muncul fiksi bernapaskan Islam yang membanjiri dunia penerbitan dan penulisan di negara ini. Dalam setiap bulannya, bahkan selalu muncul nama baru dengan karya-karyanya terbaru. Yang tengah digandrungi dewasa ini oleh masyarakat adalah karya-karya fiksi Islam mengingat isinya tidak sekadar hiburan, tetapi bermuatan pencerahan jiwa di tengah pembacanya. Tentu, ini sangat bermanfaat dalam kaitannya sebagai upaya meningkatkan wawasan dan pengetahuan, memberikan kontribusi pemahaman sekaligus keyakinan dalam hidup beragama.

Pada gilirannya, dari penjelasan terkait sastra Islam, bahwa semua karya sastra Islam, acuan dasar dalam memproduksi karyanya adalah al-Qur'an. Sebab itu, mengadopsi penjelasan Fadlil Munawwar Manshur, bahwa ketika sastrawan Muslim yang mengajak pembacanya agar tidak berkomitmen dengan Islam, yang pastinya landasannya adalah Al-Qur'an, berarti orang itu termasuk pihak yang menyimpang. ${ }^{29}$

Prinsip-prinsip normatif dapat merefer kepada Al-Qur'an sebagai kitab suci agama Islam, yang menjadi petunjuk (hudan) bagi umat ketika kitab suci itu diturunkan, namun juga bagi segenap komponen manusia. Di samping itu, tema-tema di dalamnya meliputi beragam lini kehidupan, misalnya relasi manusia dengan Pencipta, relasi manusia dan manusia, dan relasi manusia dan lingkungan semesta. Bahkan juga, ayat-ayat yang membicarakan kesemestaan (science) dan masyarakat (sosial) sebagai bentuk kenyataan yang dihadapi masyarakat dengan segenap peradaban dan kebudayaan yang penuh dinamika. Dengan begitu, ayat-ayat tersebut bisa menjadi inspirasi, motivasi, pedoman, sekaligus etika rekayasa sosial (social engineering). ${ }^{30}$ Dalam artian bahwa tatanan masyarakat yang diselaraskan dengan fakta objektif di lapangan berbasis prinsip-prinsip general dalam Al-Qur'an. Itu sebabnya, inti ajaran Qurani tidak menghendaki keseragaman sosial, namun hanya menawarkan prinsip-prinsip general tadi, yang pada gilirannya terwujud balancing dalam kehidupan di tengah masyarakat.

Dengan demikian, berdasarkan pada riset-riset sejumlah intelektual muslim terkait aspek keilmuan di dalam Al-Qur'an, mengindikasikan secara konkret adanya perkembangan berbagai disiplin dan bidang keilmuan yang diambil dari substansi ajaran Al-Qur'an. Misalnya perhatian yang dilakukan sejumlah ilmuan, terekonstruksi ke dalam sejumlah bidang; astronomi, biologi, geologi, fisika, dan kimia. Sebab itu, terkait rumusan Al-Qur'an tentang sastra menjadi tawaran konstruksi yang relatif baru di saat pergeseran kultural sastra tengah terjadi.

\section{Mengonstruksi Sistem Interpretatif Sastra Al-Qur'an}

Media kisah dimanfaatkan oleh Al-Qur'an dalam menyampaikan ajarannya. Dalam perspektif sastra, kisah yang ada di dalamnya dinyatakan sebagai produk sastra yang ranah wilayahnya adalah dunia imajinasi dan fiksi. Argumentasi ini dibangun

\footnotetext{
${ }^{28}$ Syarifudin, "Sastra Qur'ani Dan Tantangan Sastra Islam Di Indonesia.”

${ }^{29}$ Fadlil Munawwar Manshur, Perkembangan Sastra Arab Dan Teori Sastra Islam (Yogyakarta: Pustaka Pelaja, 2011).

${ }^{30}$ Azyumardi Azra, Sejarah Dan 'Ulum Al-Qur'An (Jakarta: Pustaka Firdaus, 1999).
} 
Khalaf Allah, dalam karyanya berjudul, al-Fann al-Qasasi fi al-Qur'an al-Karim yang kemudian menyimpulkan kisah dalam Al-Qur'an sebagai bentuk karya imajinatif. Untuk itu, kendati demikian, menurut Ariel Heryanto, karya sastra apa saja meski ia super imajiner, tidak mampu menghegemoni ranah otonomi mutlak, subjektif, dan bahkan tidak memiliki keterkaitan dengan pihak-pihak mana saja. Ditambahkan Leonardo Salamini, produk sastra pasti muncul pada situasi historis tertentu. ${ }^{31}$ Dengan ekspresi lain, Raman Selden menjelaskan bahwa produk sastra Al-Qur'an, bukan produk dirinya sendiri, namun sebagai produk sejarah. ${ }^{32}$

Sastra Al-Qur'an, karena itu pula, sebagai produk sejarah, mesti dianggap sebagai format konstruksi yang memiliki kompleksitas tersendiri yang terambil dari faktafakta realitas historis. Jadi, sekadar refleksi dari yang terjadi di dalam komunitas sosial, namun bisa jadi melampaui dari semua itu, sebagai suatu institusi sosial integral dari komunitas sosial, layaknya institusi-institusi sosial yang ada. Untuk itu pula, masih dalam keterangan Raman Selden, karena masih menjadi bagian integral, sastra AlQur'an tidak sekadar dipandang sebagai produk sosial, namun justru sastra Al-Qur'an menciptakan tatanan sosial kemasyarakatan. Alasannya adalah karena sastra AlQur'an juga menjadi influencer terhadap personalitas sosial itu sendiri secara normatif. Sastra Al-Qur'an dengan demikian, dapat dilihat sebagai kekuatan sosial yang mampu mengguncang masyarakat. Ujung kesimpulannya adalah bahwa sastra Al-Qur'an menjadi elemen fungsional yang sangat dibutuhkan guna mengontrol aktivitas sosial dan menjadi elemen fundamental dalam perubahan sosial, dan ini tentunya menampik sastra Al-Qur'an bukan sekadar sebagai representasi dari realitasnya semata. ${ }^{33}$

Dalam proses rentang 20 tahun lebih, telah terjadi proses konstruk teks sastra Al-Qur'an, yang di dalamnya terjadi dialektika dengan realita dan terkonstruk melalui budaya lokal ketika itu. Pada rentang selanjutnya, teks yang mengonstruk masyarakat dan memengaruhi perubahan pada budaya ke arah situasi yang diinginkan. Sebab itu, aspek teks agama, yang menjadi karakter utamanya. Ini justru menunjukkan terjadinya relasi dialektik yang cukup memiliki kompleksitas tertentu antara sastra AlQur'an dan historisnya, yang difasilitasi tidak secara langsung melalui ideologi. Ideologi itu sendiri kerap dibumbuhi kontradiksi yang menyimpan di dalamnya 'keinginan kuat' untuk mengimplementasikan penguasaan ekspresi dan makna. Sebab itulah, wajah ideologi tidak melulu satu. ${ }^{34}$

Penguasaan ekspresi dan makna yang seperti itu bisa saja memperburuk kontradiksi yang sudah ada. Kendati di lain sisi, upaya tersebut mungkin saja disertai ketundukan dari sejumlah pihak sub ordinat yang kepentingannya hendak diakomodir. Kendati kepentingannya itu secara laten tidak ditampakkan. Manakala hal ini muncul menjadi kenyataan, itu berarti ada potensi dalam penguasaan tadi, yang disebut oleh Raymon Williams, sebagai bahaya laten (emergent culture). ${ }^{35}$ Tentu saja, sisi historis dan situasi yang melatarinya selalu melekat pada sastra Al-Qur'an.

${ }^{31}$ Ariel Heryanto, "Sastra, Sejarah, Dan Sejarah Sastra," in Budaya Sastra, ed. Andy Zoeltom (Jakarta: Rajawali, 1984).

${ }^{32}$ Leonardo Salamini, The Sociology of Political Praxis: An Introduction to Gramsci's Theory (London: Routledge \& Kegan Paul, 1981).

${ }^{33}$ Raman Selden, Panduan Pembaca Teori Sastra Masa Kini (Yogyakarta: UGM Press, 1993).

${ }^{34}$ Salamini, The Sociology of Political Praxis: An Introduction to Gramsci's Theory.

${ }^{35}$ Raymon Williams, Problems in Materialism and Culture: Selected Essays (London: Merlin Press, 1973).

156 | at-@urhan: Kajian Ilmu dan Pengembangan Budaya Al-Qur'an, Vol. 20, No. 1, Juni 2020: 129-163. 


\section{Abd. Aziz}

Apalagi, selalu muncul konflik ideologi kekuasaan dalam sejarah itu sendiri, dan ini yang menyebabkan sastra Al-Qur'an tidak terpisahkan dengan konflik tersebut. Konteks ini, Al-Qur'an bukan saja mengartikulasikan ideologi yang tengah dikonstruk, namun juga menanggapi eksistensi konstruk itu sendiri yang dapat menyebabkan munculnya kesadaran faktual dan kesadaran yang nisbi. Kalau begitu, maka sastra AlQur'an bukan sebagai produk ideologi, namun sebagai sesuatu yang begitu dibutuhkan dalam merekonstruksi sosialnya. Kendati seperti itu, tidak bisa dialihkan, bahwa sastra Al-Qur'an sebagai teks, terlihat seolah 'tanpa beban' dalam berinteraksi dengan segala apa saja yang dianggap sebagai realita, namun sastra Al-Qur'an tidak otonom dari pemanfaatan ideologi.

Uniknya, refleksi reproduksi yang dilakukan sastra Al-Qur'an terhadap konflikkonflik di atas, tidak dilakukan dalam format yang sama utuh ketika terjadi di dalam sejarahnya. Sebab, ideologinya juga tidak dominan berada dalam teks sastra Al-Qur'an itu sendiri, sehingga dapat dikatakan terjadi distorsi di dalamnya. Ini yang kemudian sastra Al-Qur'an mengambil posisi untuk mempertanyakan sisi fundamental terhadap realita-realita yang dalam beberapa aspek diterima di khalayak umum. Keunikan ini yang kadangkala menggagalkan beberapa penafsir - dengan pendekatan historis yang digunakannya - untuk mengeksplorasi segala anasir historis dalam sastra Al-Qur'an. Oleh sebab itu, tidak mengherankan manakala kejadian-kejadian atau pun materimateri yang didapatkan, tidak sepenuhnya sama ketika diekspresikan.

Untuk dalam suatu kesempatan tertentu, pendekatan sejarah, kadangkala kurang efektif dalam memahami misteri-misteri yang ada dalam cerita-cerita AlQur'an. Dalam konteks ini, sastra Al-Qur'an dibutuhkan untuk menjadi sistem interpretasi, yang dapat dimengerti ketika diposisikan dalam konteks ideologi. Dan, lagi-lagi, sastra Al-Qur'an menawarkan dan sekaligus menyarankan sesuatu yang bukan dalam bentuk sebenarnya. Sastra Al-Qur'an yang demikian, diistilahkan Goenawan Mohammad, sebagai pasemon atau sindiran halus, namun arahnya menjurus kepada deskripsi tertentu yang spesifik. ${ }^{36}$ Ini artinya bahwa secara apriori, makna tidak begitu saja tampak dalam pasemon. Makna diibaratkan sesuatu yang dapat tampak dalam konteks tertentu ketika mengomparasikan dengan suatu keadaan atau dengan suatu ekspresi dalam forman yang lain.

Bila meminjam istilah dalam studi psikoanalisa, pasemon ini merupakan sesuatu yang berada dalam kondisi ketidaksadaran (unconscious), kemudian diekspresikan tidak dengan cara yang hendak diekspresikan tersebut. Situasi ini seperti format yang ada dalam suatu wacana, tetapi format itu tidak berformat. Jika dalam situasi mimpi seseorang, ini merupakan mimpi yang bahasanya tidak bertata (mode of disorder). Sesungguhnya, format seperti itu belum pernah diekspresikan secara nyata. Kadangkala ada sesuatu yang hendak diekspresikan, namun tidak pernah ada di dalam ekspresi yang diungkapkan itu. ${ }^{37}$ Ini menjadi semacam sejarah yang tertindas, suatu istilah yang digunakan Freudian, untuk menjelaskan sesuatu yang tidak diekspresikan, sehingga menjadi tidak tampak. Ini artinya, konflik-konflik atau penindasan itu kerap wujud. Sebab itu, seringkali muncul realitas dalam sastra sebagai pembanding atas realitas lain yang terjadi, dan ini kemudian dikonstruk oleh sastra menjadi kisah atau cerita. Manakala menjadi suatu kisah atau cerita, maka dalam pandangan Friederic

\footnotetext{
${ }^{36}$ Goenawan Mohamad, "Kesusastraan, Pasemon," Kompas, 1992.

${ }^{37}$ Michel Foucault, "Maurice Blanchot: The Thought from Outside," in Foucault/Blanchot, ed. Anonym (Zone Books, 1987).
} 
Jameson, sastra yang dalam bentuk cerita tersebut masuk ke dalam ranah epistemologi esensialis yang sangat membutuhkan interpretasi. ${ }^{38}$

Dalam konteks korelasinya dengan sastra Al-Qur'an, ini berarti sastra Al-Qur'an mengekspresikan sesuatu untuk sesuatu yang lain. Artinya, ekspresi deklaratif di dalamnya, bukan untuk kepentingan dirinya, namun dalam rangka memperkuat worldview Al-Qur'an tersebut. Di luar itu, masuklah pendekatan kritik teks - jika memang diperlukan - untuk mendapatkan segala kemungkinan yang tidak terekspresikan dalam sastra Al-Qur'an. Bisa jadi, kemungkinan yang dimaksud mengakomodasi keinginan-keinginan komunal dalam masyarakat. Segenap keinginan tersebut dapat tercover melalui tindakan dan tata verbal tokoh-tokoh dalam cerita. Salah satu cara lain untuk memperoleh keinginan-keinginan yang lebih kongkret adalah dengan mencermati konflik-konflik yang terjadi antara sesuatu yang terekspresikan dan situasi atau cara pengekspresian tata verbalnya. Hal ini dilakukan karena terjadi kontradiksi antara situasi atau cara ekspresi dan sesuatu yang diekspresikan. ${ }^{39}$ Inilah yang dialami oleh para kritikus teks dalam menghadapi pembacaan sastra Al-Qur'an. Ada semacam gangguan secara kultural dan tekstual dalam dirinya.

Inferensi dari sub tema ini adalah dominasi suatu ideologi di dalam sejarah, tidak semata-mata menghegemoni eksistensinya terhadap sastra Al-Qur'an. Sebab, pembacaan terhadap teks, selalu vis a vis dengan nilai yang telah mapan di lingkungan sosialnya. Dengan kata lain, untuk itu, sastra Al-Qur'an memiliki kuasa dalam melakukan perubahan tatanan dan nilai sosial di masyarakat. Kendati misalnya, manakala value yang dominan itu setara dengan value yang ada dalam sastra $\mathrm{Al}$ Qur'an, itu berarti sastra Al-Qur'an mendudukkan posisinya sebagai penguat segenap konstruk dan tatanan sosialnya.

\section{Relasi Sastra, Al-Qur'an, Dan Agama}

Untuk dapat memilih dan menerima bahan-bahan yang berasal dari budaya dan agama itu dituntut adanya rujukan dan pertimbangan yang memadai. Salah satunya adalah adanya hubungan yang erat antara sastra dan agama, mengingat keduanya memiliki persamaan yang fundamental soal nilai-nilai perasaan yang luhur ${ }^{40}$. Oleh karena itu, seringkali sastra memilih nilai agama sebagai temanya dan agama memilih sastra sebagai media untuk menyampaikan ajarannya.

Sejak awal terbentuknya, Al-Qur'an memang sudah bersentuhan dengan tradisi kesusasteraan Arab yang sudah mapan, yaitu sastra Jahiliah. Ketika interaksi itu berlangsung dan supremasi Al-Qur'an begitu dominan, maka Al-Qur'an, dalam kapasitasnya sebagai dustur Islam, hadir sebagai ide sentral sekaligus solusi pemecah persoalan. Secara sederhana interaksi yang terjadi antara Al-Qur'an dan kesusasteraan berkisar pada tiga persoalan. Pertama, persoalan yang berhubungan dengan konsep estetika, hubungan antara karya sastra dan filsafat keindahan dalam ruang transenden ('aqidah). Kedua, rujukan yang mengarah pada etika (akhlaq) serta kaitannya dengan hakikat sastra dan tujuannya dalam konteks sosiologis. Ketiga, masalah perbedaan

\footnotetext{
${ }^{38}$ Raman Selden, Panduan Pembaca Teori Sastra Masa Kini, trans. Rachmat Djoko Pradopo (Yogyakarta: Gadjah Mada University Press, 1991).

${ }^{39}$ Terry Eagleton, Literary Theory, An Introduction (England: Basi Blackwell Publisher Limited, 1983).

${ }^{40}$ Nyoman Tusthi Eddy, Nukilan I: 15 Esei Tentang Sastra (Flores: Nusa Indah, 1983).
}

158 | al-هurhan: Kajian Ilmu dan Pengembangan Budaya Al-Qur'an, Vol. 20, No. 1, Juni 2020: 129-163. 


\section{Abd. Aziz}

wacana dan pendekatan terhadap ekspresi dan proses kreatif dalam konteks tafsir hukum agama (shari'ah). ${ }^{41}$ Untuk itu, sekali lagi, penulis tegaskan, dalam perspektif Al-Qur'an, tujuan utama sastra adalah membangun dan menggairahkan kerinduan manusia kepada Tuhan-nya (dimensi spiritual) dan menyadarkan manusia atas diri dan lingkungannya (dimensi moral). ${ }^{42}$ Oleh karena itu, sebagai sumber yang melengkapi setiap momentum estetika, Al-Qur'an dengan tegas mensyaratkan adanya keterpaduan antara dua entitas yang berbeda dalam sebuah ruang keindahan. Entitas yang dimaksud adalah dunia nyata (realitas objektif) dan dunia yang dibayangkan (realitas imajinatif) (QS. al-Shu'ara'/26: 224). ${ }^{43}$

Nilai etika atau moral dalam sastra yang baik akan memberikan wawasan terhadap pencerahan pemikiran dan spiritual serta mampu mendidik, memberikan etika terhadap perkembangan perilaku pembaca. Banyak orang memahami bahwa etika atau moral dan estetika merupakan nilai keindahan dalam sebuah sastra. Sastra tidak akan lepas dari budaya kehidupan. Setiap sastra walaupun sebagian cerita mengandung kisah percintaan tetapi jika terdapat nilai-nilai ideologi, moral dan kemanusiaan di dalamnya maka sastra tersebut, tetap menjadi sastra yang berbobot dan lebih bersifat abadi. ${ }^{44}$

Agama dan sastra merupakan dua bagian yang dapat saling berkaitan. Atmosuwito mengatakan bahwa sastra juga adalah merupakan bagian dari agama. ${ }^{45} \mathrm{Di}$ dalam agama terdapat nilai-nilai yang dapat diambil pelajarannya oleh masyarakat pada umumnya, khususnya para pecinta sastra. Apalagi kaitan hal ini sastra membutuhkan ilmu lain dalam mengembangkan dan meningkatkan kualitas isi sebuah karya sastra. Sebuah sastra hanya akan berguna jika dikaitkan dengan faktorfaktor lain di luar sastra. ${ }^{46}$ Dalam hal ini adalah kaitan sastra dan nilai-nilai ajaran keagamaan yang selalu diistilahkan sebagai pesan moral. Melalui karya sastranya, para pengarang ingin menyosialisasikan ide-ide moral yang dapat menggiring pembaca untuk menikmati pesan moral yang ditulisnya seperti nilai-nilai baik dan buruk sebagai norma yang berlaku di masyarakat.

Penelaahan atas unsur agama dalam karya sastra sampai saat ini tidak pernah surut. Sebaliknya, hal tersebut justru menumbuhkembangkan penafsiran-penafsiran baik yang berkaitan dengan suatu kepercayaan terhadap Tuhan maupun tradisi kehidupan keagamaan yang dimuat di dalam karya sastra. Karenanya, dipandang perlu suatu penelaahan dengan penekanan pada unsur religiositas sebuah karya sastra guna mendapatkan nilai-nilai ajaran agama yang dituliskan pengarang melalui karyanya. Senada dengan ungkapan Mangunwijaya, yang mengatakan bahwa setiap karya sastra yang berkualitas selalu berjiwa religious. Hal itu semakin memperkuat bahwa di dalam sastra terkandung nilai, norma, dan agama. Dikarenakan seorang penulis karya sastra

\footnotetext{
${ }^{41}$ Salad, Agama Seni: Refleksi Teologis Dalam Ruang Estetik.

${ }^{42}$ James, Islamic Art: An Introduction.

${ }^{43}$ QS. al-Shu'ara' [26]: 224:

"Dan penyair-penyair itu diikuti oleh orang-orang yang sesat."

${ }^{44}$ Syarifudin, "Sastra Qur'ani Dan Tantangan Sastra Islam Di Indonesia."

${ }^{45}$ Subijantoro Atmosuwito, Perihal Sastra Dan Religiusitas Dalam Sastra (Bandung: Sinar Baru,

${ }^{46}$ David Hill Radcliffe, "Romanticism and Gendre: Theory and Practice," Eighteenth-Century
} 1989). Life 36, no. 1 (December 2012). 
dilahirkan dari lingkungan tertentu, sehingga pengalamannya serta pengaruh sosialnya akan berpengaruh terhadap karya-karya sastra yang dihasilkannya ${ }^{47}$.

Adanya pengaruh agama dalam sastra dapat dilihat dari bagaimana peran dan fungsi sastra itu terhadap masyarakat. Sastra jika dilihat dari fungsinya di dalam masyarakat masih terbilang wajar khususnya dalam masalah hubungan antara fungsi estetik dan fungsi lain seperti fungsi sosial dan agama. Adapun fungsi estetiknya perlu dikaji pada bentuk dan isinya, misalnya dalam pemakaian kata atau kalimat yang berhubungan dengan agama Islam, serta yang berkaitan dengan isi ajaran Islam atau yang berhubungan dengan Nabi Muhammad Saw dan para sahabatnya. Fungsi seperti itu, merupakan kekayaan sastra lisan yang sangat besar manfaatnya bagi masyarakat sekarang yang sampai saat ini ciptaan itu selalu mempunyai nilai dan fungsi bagi masyarakat Indonesia. Hal ini memiliki kesamaan dengan pendapatnya Ben-Annos yang mengemukakan bahwa makna sastra lisan harus dilihat dari konteks budayanya, dengan demikian maknanya akan dapat dirujuk pada tempat dan situasi pada saat pengucapannya. ${ }^{8}$

Secara sederhana interaksi yang terjadi antara al-Qur'an dan kesusasteraan berkisar pada tiga persoalan. Pertama, persoalan yang berhubungan dengan konsep estetika, hubungan antara karya sastra dan filsafat keindahan dalam ruang transenden ('akidah). Kedua, rujukan yang mengarah pada etika (akhlaq) serta kaitannya dengan hakikat sastra dan tujuannya dalam konteks sosiologis. Ketiga, masalah perbedaan wacana dan pendekatan terhadap ekspresi dan proses kreatif dalam konteks tafsir hukum agama (shari'ah). ${ }^{49}$ Kendati demikian, perlu menganalisis dan menafsirkan AlQur'an dan tradisi autentik nabi menurut latar belakang kontekstual tempat mereka muncul. Dengan kata lain, kalau keduanya tidak bisa dipahami dengan benar pesan Islam tidak akan memiliki pengaruh kuat bagi orang yang pertama menerima pesannya, dan mereka hendaknya dipahami dalam konteks sosio-budaya sendiri, pemahaman, dan aplikasi mereka dengan masyarakatnya yang mengalami perubahan. Namun, pemahaman generasi muslim pertama dan generasi selanjutnya tidak perlu dianggap sebagai pemahaman yang final atau absolut. Linguistik yang spesifik mengodekan (encoding) dinamika teks Al-Qur'an yang selalu memungkinkan sebuah proses pengodean yang tidak pernah berakhir. Dalam proses ini, makna sosio-budaya kontekstual tidak bisa diabaikan atau disederhanakan karena 'makna' ini sangat vital bagi petunjuk pesan 'baru' dari teks tersebut. Petunjuk ini memfasilitasi perkembangan dari 'makna' pada 'signifikansi' konteks sosio-budaya saat ini. ini juga memberikan kemampuan kepada seorang penafsir secara akurat dan efisien untuk menggali 'sejarah' dan 'temporal' yang tidak membawa signifikansi dalam konteks saat ini. Interpretasi adalah sisi lain yang tidak bisa dipisahkan dari teks. Al-Qur'an, yang dikodekan menurut konteks sejarah, budaya, dan linguistiknya, yang kemudian dikodekan kembali ke dalam kode konteks budaya dan linguistik penafsir ${ }^{50}$. Dengan kata lain, struktur-struktur dalam (deep structure) Al-Qur'an mesti direkomendasikan

${ }^{47}$ Erli Yetti, "Religiusitas Dalam Novel Sastra Indonesia: Studi Kasus Khotbah Di Atas Bukit Karya Kuntowijoyo," Sawomanila, n.d.

${ }^{48}$ Moh. Karmin Baruadi, "Sendi Adat Dan Eksistensi Sastra; Pengaruh Islam Dalam Nuansa Budaya Lokal Gorontalo," El Harakah 14, no. 2 (2012).

${ }^{49}$ Salad, Agama Seni: Refleksi Teologis Dalam Ruang Estetik.

${ }^{50}$ Wahid, Studi Al-Quran Kontemporer Perspektif Islam Dan Barat. 


\section{Abd. Aziz}

dari struktur permukaan (surface structure). Setelah itu, struktur dalam harus dituliskan kembali dalam struktur permukaan lainnya yang ada pada saat sekarang.

\section{Kesimpulan}

Mengakhiri tulisan ini perlu ditegaskan kembali bahwa konsepsi al-Qur'an tentang sastra adalah cadangan pilihan-pilihan paradigmatik yang tidak wajib dipilih bagi sastra Indonesia. Dia adalah varian saja dalam rentangan sejarah sastra Indonesia. Hanya saja, Format tawaran sastra Al-Qur'an dalam tulisan ini dapat diamati melalui pengalaman menghubungkan seni estetik, seni penciptaan imajinasi, dan fakta kehidupan. Sastra Al-Qur'an dapat merekatkan antara seni, agama, sastra, dan AlQur'an ke dalam lingkaran korelatif, sehingga menghasilkan value, pesan etik, sekaligus juga filsafat profetik. Tentu saja, konstruksi relasi ini tidak mendarat kepada titik akhir suatu kesimpulan absolut. Karena memang, diperlukan jalinan dialektik tersendiri untuk mengonstruk Al-Qur'an sebagai basis inspirasi bagi sastra, dengan kemandirian sastra itu sendiri sebagai realita imajinatif edukatif untuk kemaslahatan publik yang lebih luas.

\section{Daftar Pustaka}

Ahmad, M. Membumikan Islam Di Indonesia. Gorontalo: Panitia Seminar Nasional, 
2003.

Al-Karim, Hassan 'Abd. Al-Tasawwuf Fi Al-Shi'r Al-'Arabi, Nash'Atuhu Wa Tatawwuruhu Hatta Akhir Al-Qarn Al-Thalith Al-Hijri. Kairo: Maktabah al-Anjilu al-Misriyyah, 1954.

Al-Qa'ud, Hilmi Muhammad. Al-Waqi'iyyah Al-Islamiyyah Fi Riwayat Najib Al-Kaylani, Dirasah Naqdiyyah. Riyad: Maktabah al-'Abikan, n.d.

Atmaja, Jiwa. Notasi Tentang Novel Dan Semiotika Sastra. Ende: Nusa Indah, 1986.

Atmosuwito, Subijantoro. Perihal Sastra Dan Religiusitas Dalam Sastra. Bandung: Sinar Baru, 1989.

Aziz, Abd, Athoillah Islamy, and Saihu. "Existence of Naht Method in the Development of Contemporary Arabic Language." Taqdir: Jurnal Pendidikan Bahasa Arab Dan Kebahasaaraban 5, no. 2 (2019): 19-28. https://doi.org/https://doi.org/https://doi.org/10.19109/taqdir.v5i2.4926.

Aziz, Abd, and Saihu Saihu. "Interpretasi Humanistik Kebahasaan: Upaya Kontekstualisasi Kaidah Bahasa Arab.” Arabiyatuna: Jurnal Bahasa Arab 3, no. 2 (2019): 299. https://doi.org/10.29240/jba.v3i2.100o.

Azra, Azyumardi. Sejarah Dan 'Ulum Al-Qur'An. Jakarta: Pustaka Firdaus, 1999.

Baruadi, Moh. Karmin. "Sendi Adat Dan Eksistensi Sastra; Pengaruh Islam Dalam Nuansa Budaya Lokal Gorontalo.” El Harakah 14, no. 2 (2012).

Brown, Dan. The Davinci Code. Translated by Isma B. Koesalamwardi. Vol. XXIII. Jakarta: Serambi, 2006.

Eagleton, Terry. Literary Theory, An Introduction. England: Basi Blackwell Publisher Limited, 1983.

Eddy, Nyoman Tusthi. Nukilan I: 15 Esei Tentang Sastra. Flores: Nusa Indah, 1983.

Fang, Liaw Yock. Sejarah Kesusastraan Melayu Klasik Jilid I. Jakarta: Erlangga, 1991.

Foucault, Michel. "Maurice Blanchot: The Thought from Outside." In Foucault/Blanchot, edited by Anonym. Zone Books, 1987.

Heryanto, Ariel. "Sastra, Sejarah, Dan Sejarah Sastra." In Budaya Sastra, edited by Andy Zoeltom. Jakarta: Rajawali, 1984.

Isnaini. H. "Gagasan Tasawuf Pada Kumpulan Puisi Isyarat Karya Kuntowijoyo." Tesis, 2012, 87-99.

Isnaini, Heri. "Gagasan Tasawuf Pada Kumpulan Puisi Isyarat Karya Kuntowijoyo." Semantik, n.d.

James, David. Islamic Art: An Introduction. London-New York: Hamlyn, 1974.

Kamil, Sukron. Najib Mahfuz, Sastra Islam Dan Politik, Studi Semiotik Terhadap Novel Aulad Haratina. 1. Jakarta: Dian Rakyat, 2013.

Manshur, Fadlil Munawwar. Perkembangan Sastra Arab Dan Teori Sastra Islam. Yogyakarta: Pustaka Pelaja, 2011.

Mohamad, Goenawan. "Kesusastraan, Pasemon.” Kompas, 1992.

Nasional, Departemen Pendidikan. Kamus Tesaurus Bahasa Indonesia. Jakarta: Pusat Bahasa, 2008.

Radcliffe, David Hill. "Romanticism and Gendre: Theory and Practice." EighteenthCentury Life 36, no. 1 (December 2012).

Salad, Hamdy. Agama Seni: Refleksi Teologis Dalam Ruang Estetik. Yogyakarta: Yayasan Semesta, 2000.

-_- Refleksi Teologis Dalam Ruang Estetik. Yogyakarta: Yayasan Semesta, 2000.

Salamini, Leonardo. The Sociology of Political Praxis: An Introduction to Gramsci's

162 | al-\$urhan: Kajian Ilmu dan Pengembangan Budaya Al-Qur'an, Vol. 20, No. 1, Juni 2020: $129-163$. 
Abd. Aziz

Theory. London: Routledge \& Kegan Paul, 1981.

Santoso, and Dan Dkk. Sastra Keagamaan Dalam Perkembangan Sastra Indonesia: Puisi 1946-1965. Jakarta: Pusat Bahasa, Departemen Pendidikan Nasional, 2004.

Saraswati, Ekarini. "Pribadi Dalam Novel Ayat-Ayat Cinta Dan Laskar Pelangi: Telaah Psikoanalisis Sigmund Freud.” Artikulasi 12, no. 2 (2011): 883.

Saridjo, Marwan. Sastra Dan Agama, Tinjauan Kesusastraan Indonesia Modern Bercorak Islam. Jakarta: Permadani, 2006.

Selden, Raman. Panduan Pembaca Teori Sastra Masa Kini. Translated by Rachmat Djoko Pradopo. Yogyakarta: Gadjah Mada University Press, 1991.

_-_ Panduan Pembaca Teori Sastra Masa Kini. Yogyakarta: UGM Press, 1993.

Supriadi, Asep. “Transformasi Nilai-Nilai Ajaran Islam Dalam Ayat-Ayat Cinta Karya Habiburrahman El-Shirazy: Kajian Interteks," 2006.

Syarifudin, Moh. "Sastra Qur'ani Dan Tantangan Sastra Islam Di Indonesia,” Vol. XII, n.d.

W.M., Abdul Hadi. Islam, Cakrawala Estetik Dan Budaya. Jakarta: Pustaka Firdaus, 2000.

Wahid, Marzuki. Studi Al-Quran Kontemporer Perspektif Islam Dan Barat. Bandung: CV. Pustaka Setia, 2005.

Wildana, W, and Laily Fitriani. Sastra Arab Dan Lintas Budaya. Malang: UIN-Malang Press, 2008.

Williams, Raymon. Problems in Materialism and Culture: Selected Essays. London: Merlin Press, 1973.

Yetti, Erli. "Religiusitas Dalam Novel Sastra Indonesia: Studi Kasus Khotbah Di Atas Bukit Karya Kuntowijoyo." Sawomanila, n.d.

Zaydan, Yusuf. Diwan 'Abd Al-Qadir Al-Jilani. Beirut: Dar al-Jil, n.d. 